\title{
Possible coupling of anaerobic methane oxidation (AOM) and anammox in cold wetland soils
}

\author{
HEATHER R TOWNSEND ${ }^{1}$, FEREIDOUN \\ REZANEZHAD $^{1}$, STEPHANIE SLOWINSKI ${ }^{1}$, CHRISTINA \\ SMEATON $^{2}$, MERRIN MACRAE $^{1}$, CHRISTOPHER $^{2}$ \\ PARSONS $^{3}$, KARA WEBSTER ${ }^{4}$ AND PHILIPPE VAN \\ CAPPELLEN $^{1}$
}

${ }^{1}$ University of Waterloo

${ }^{2}$ Memorial University of Newfoundland (Grenfell Campus)

${ }^{3}$ Environment and Climate Change Canada, Canada Centre for Inland Waters

${ }^{4}$ Natural Resources Canada

Presenting Author: heather.townsend@uwaterloo.ca

In cold regions, snow and frozen soil conditions uniquely affect subsurface biogeochemical processes during the winter season by decreasing, or even halting, water movement and gas exchanges with the atmosphere. This may result in a seasonally anoxic soil system and methane $\left(\mathrm{CH}_{4}\right)$ build-up below the snowpack. Oxidation of $\mathrm{CH}_{4}$ to carbon dioxide $\left(\mathrm{CO}_{2}\right)$ through anaerobic pathways may limit $\mathrm{CH}_{4}$ emissions; however, the electron $\left(e^{-}\right)$acceptors responsible for anaerobic methane oxidation (AOM) in soils have remained evasive. In this study, a series of sacrificial batch experiments were conducted to simulate winter conditions in an organic soil collected from a swamp in the Turkey Lakes Watershed near Sault Ste. Marie, Ontario, Canada. Homogenized soil was amended with solutions containing variable quantities of labile organic $\mathrm{C}$ and $e^{-}$acceptors (nitrate and sulfate) and incubated at $5^{\circ} \mathrm{C}$ under anoxic conditions over 50 days. Samples collected at 6 timepoints were analyzed for headspace gas concentrations, porewater chemistry, and genomic sequencing. Oxidation of both inorganic and organic $e^{-}$ donors was observed, consuming up to $8 \mathrm{mM}$ acetate and $2 \mathrm{mM}$ ammonium $\left(\mathrm{NH}_{4}^{+}\right)$and at least $0.1 \mathrm{mM} \mathrm{CH}$. Furthermore, during the later stage of the experiment, nitrate production by the anaerobic oxidation of ammonium (anammox) co-occurred with AOM, suggesting a possible link between the two metabolisms. AOM increased porewater $\mathrm{pH}$ from 5.4 to 6.5 , causing a negative feedback that progressively reduced AOM's thermodynamic driving force. Bioenergetics-based calculations and genomic sequencing further identified manganese $(\mathrm{Mn})$ oxides as the most likely $e^{-}$acceptor for the oxidation of $\mathrm{NH}_{4}^{+}$, whereas the sequencing data indicated the concomitant increase in the relative abundances of metal-reducing and $\mathrm{CH}_{4}$ oxidizing bacteria. We, therefore, speculate that the microbial soil consortium coupled AOM to Mn-oxide mediated anammox. 